\title{
Juvenile cataract-microcornea-renal glucosuria syndrome
}

INSERM

\section{Source}

INSERM. (1999). Orphanet: an online rare disease and orphan drug data base. Juvenile cataract-microcornea-renal glucosuria syndrome. ORPHA:247794

Juvenile cataract - microcornea - renal g lucosuria is an extremely rare autosomal dominant association reported in a single Swiss family and characterized clinically by juvenile cataract associated with bilateral microcornea, and renal glucosuria without other renal tubular defects. 